\title{
RESPECTING THE DIGNITY OF THE HUMAN PERSON IN THE EXECUTION OF SENTENCES AND FREEDOM-DEPRIVING MEASURES RULED BY THE JUDICIARY BODIES DURING A CRIMINAL TRIAL
}

\author{
I. Bratiloveanu*
}

\section{Izabela Bratiloveanu}

Faculty of Law and Social Sciences, University of Craiova, Craiova, România

*Correspondence: Bratiloveanu Izabela, Craiova, 8 Horia St., B1. E2, sc.2, ap.2

Abstract

Through Law no. 254/2013 on the execution of punishments and custodial measures ordered by the court in criminal proceedings, continue changing the approach of the treatment of detainees. Transposition of human dignity in the prison environment involves a radical change in conceptions about prison, inmate and his treatment.

Key-words: The dignity of the human person; punishments; conditions of detention.

Introduction

Ensuring the respect of the dignity of the human person in the prison environment corresponds to all the which makes a person respect another one. This respect is not always automated, and laws must ensure that it is guaranteed. Whereas dignity is and intrinsic and unalienable quality of every human person, the respect thereof can be affected by the exclusion of certain persons from the human family, by seeing them unfit to be accepted as members of the society. Or, ,as each man bears within himself the whole form of the human condition"1, regardless of their deeds, characteristics and qualities, the detainee must be treated as a human person, who is part of the humain family.

\section{The dignity of the human person and the penal execution law}

In 1945, the United Nations Organization was created in order to maintain international peace and security, help nations develop friendly relationships, achieve international cooperation and be a centre for the member nations to harmonize their efforts in view of achieving their set objectives. The Charter of the United Nations was signed in San Francisco on the 26th of June 1945 and it came into force as of the 24th of October 1945. In its Preamble it is stated ,the faith in the fundamental human rights, in the dignity and value of the human person". The Universal Declaration of Human Rights, adopted by the U.N. General Assembly on the 10th of September 1948, is the first global statement that dignity is "inherent to all members of the human family". Dignity , refers to the idea that no one can be excluded from the human community. Respecting dignity is respecting each individual for that which makes them a human, respectable being. Denying this part of humanity turns the individual into a servile human being, it degrades them and integrates them into a lower class" ${ }^{2}$, as mentioned by J.-M. Larralde.

\footnotetext{
* My contribution at this work was supported by the strategic grant POSDRU/159/1.5/S/141699, Project ID 141699, co-financed by the European Social Fund within the Sectorial Operational Program Human Resourses Development 2007 - 2013.

${ }^{1}$ M. De Montaigne, Essais, „P.U.F.” Publishing House, Paris, 1992, p.804.

2 J.-M. Larralde, Placement sous écrou et dignité de la personne, séance inaugurale du séminaire de recherche „Enfermement, Justice et Libertés”, Université Paris I Panthéon-Sorbonne, 15 septembrie 2009.
} 


\section{RESPECTING THE DIGNITY OF THE HUMAN PERSON IN THE EXECUTION OF SENTENCES AND FREEDOM-DEPRIVING MEASURES RULED BY THE JUDICIARY BODIES DURING A CRIMINAL TRIAL}

The same ideas are stated in the International Pact on Civil and Political Rights signed in New-York on the 16th of December 1966. The pact "makes modern humanism enter the prison environment"3. According to art. 10.1 of the Pact, any person deprived of their liberty "shall be treated with humanity and with respect for the inherent dignity of the human person". Ever since 1962, the Council of Europe has introduced the principle of dignity in the prison environment: thus, the preamble to the Resolution on voting, civil and social rights of the detainee included a statement of the will "to promote a prison system in the member states of the Council of Europe, that is able to ensure society protection in the respect of human dignity"4.

Also, the Convention against Torture and Other Cruel, Inhuman or Degrading Treatment or Punishment adopted in New York on the 10th of December 1984, explicitly admits that "the equal and inalienable rights of all members of the human family (...) derive from the inherent dignity of the human person". According to art. 1 of the Convention, the torture means any act by which severe pain or suffering, whether physical or mental, is intentionally inflicted on a person for such purposes as obtaining from him or a third person information or a confession, punishing him for an act he or a third person has committed or is suspected of having committed, or intimidating or coercing him or a third person, or for any reason based on discrimination of any kind, when such pain or suffering is inflicted by or at the instigation of or with the consent or acquiescence of a public official or other person acting in an official capacity. The term does not include pain or suffering arising only from, inherent in or incidental to lawful sanctions.

The fundamental principles related to the treatment of detained persons ${ }^{5}$ adopted by the U.N. General Assembly follow the same guideline and stipulates that detainees be treated with the respect that is owed to the dignity and inherent value of a human being and that no discrimination should arise in terms of race, colour, sex, language, religion, opinion, national or social background, wealth, birth or station. Principle number 5 stipulates that, except for the case in which restraints through incarceration are obviously necessary, all detainees must still benefit from the respect of the human rights and of the fundamental freedoms mentioned in the Universal Declaration of Human Rights, in the International Pact on Economic, Social and Cultural rights, in the International Pact on Civil and Political Rights, in the facultative protocols to the pact, as well as in the other rights stipulated in other UN pacts. In the penal execution law, penal humanism provides meaning and existence to the subjective rights of the detainees, "unconditionally legitimized by dignity, which is an inherent quality of the human being and can therefore be attributed to any detainee"6.

Starting from the idea that incarceration is a punishment in itself by depriving a person of their liberty, the European Prison Rules adopted by the Committee of Ministers of the member states of the Council of Europe on the 11th of January 2006, included a set of fundamental principles, respectively: all persons deprived of their liberty shall be treated with respect for their human rights; persons deprived of their liberty retain all rights that are not lawfully taken away by the decision sentencing them or remanding them in custody; restrictions placed on persons deprived of their liberty shall be the minimum necessary and proportionate to the legitimate objective for which they are imposed; prison conditions that infringe prisoners' human rights are not justified by lack of resources; life in prison shall approximate as closely as possible the positive aspects of life in the community; all detention shall be managed so as to facilitate the reintegration into free society of persons who have

\footnotetext{
${ }^{3}$ S. Tzitzis, Humanisme, dignité de la personne et droits des détenus, Etudes et analyses de l'Institut pour la Justice, decembrie 2009, p.13.

${ }^{4}$ Resolution no. 62(2) of the Ministers' Deputies of the $1^{\text {st }}$ of February 1962.

${ }^{5}$ Resolution no. 45/111, of the 14th of December 1990.

${ }^{6}$ S. Tzitzis, work cited, p. 20 .
} 


\section{Bratiloveanu}

been deprived of their liberty. There are 108 European Prison Rules and they focus on the rights of the detainees, detention conditions, health, order, prison management and staff, inspection and control. This set of rules, divided into 8 parts describes the means of making detention compatible with the respect of human dignity.

In its turn, the European Court of Human Rights has decided on several occasions that the respect of human dignity is part of the very essence of the Convention ${ }^{7}$ and that human rights form an integrated system in view of protecting the dignity of the human being ${ }^{8}$. The comprehensive jurisprudence of the European institution influences internal laws, by imposing various requirements related to the respect of human dignity, indirectly by banning torture and other cruel, inhuman or degrading treatment or punishment, as stipulated in art.3. The European Court considers that freedom-depriving measures usually involve suffering or humiliation, therefore ordinary detention is not subject to art. 3 of the Convention. Starting from the ruling in the case Kudla against Poland ${ }^{9}$, the European court has shown that art. 3 of the Convention urges states to ensure that all prisoners are detained in such conditions as to respect human dignity, that the means of executing the respective measure do not subject the person to suffering or trials the intensity of which goes beyond the inherent level of detentionrelated suffering and that, while taking into account the practical requirements of the prison environment, the prisoner's welfare and health are properly ensured. The European Court estimates that, regardless of the financial or logistic difficulties that the contracting states may face, they must set up a prison system that ensure that detainees are treated with respect for their human dignity.

In terms of the states' negative obligation that their agents may not inflict torture, inhuman or degrading treatments in the prison environment, the jurisprudence of the European Court has progressively moved towards the „humanization” of certain prison practices ${ }^{10}$. The use of force against detainees, which used to be seen as compliant with the requirements of art. 3 of the European Convention in the older jurisprudence of the Court, are currently seen as violating conventional dispositions. Torturing involves denying the detainee's humanity, or dignity appears to be a "positive counterpart of subjugation and degradation" 11 , and any action meant to turn a person into an object, to instrumentalize them is condemnable. The analysis carried out by the Court is based on the idea that, when a person is deprived of their liberty, the use of physical force against them, if it proves to be unnecessary on account of the victim's behaviour, can only prove injurious of their human dignity and is basically a violation of the right provided for in art. $3^{12}$. Moreover, the absolute nature of physical integrity results in the fact that the source of danger - translated into physical damage - is of little to no importance, as it may originate from other people who are not state agents ${ }^{13}$. Consequently, art. 3 of the European Convention of Human Rights imposes upon the states a positive obligation to take whatever measures are necessary to prevent detainees from recurring to torture, inhuman or degrading treatments towards their fellow detainees.

\footnotetext{
${ }^{7}$ Case of Pretty v. the United Kingdom, petition nr. 2346/02, §65, ECHR 2002-III; Case of Svinarenkp and Slyadnev v. Russia, petitions nr. 32541/08 and 43441/08, the Grand Chamber, ruling of the 17th of July 2014, $\S 118$.

${ }^{8}$ Case of Prosperity Party and others v. Turkey, petitions nr. 41340/98, 41342/98, 41343/98 and 41344/98, ruling of the 31st of July 2001, $\$ 43$.

${ }^{9}$ Case of Kudla v. Poland, petition nr. 30210/96, ruling of the 26th of October 2000, $\$ 94$.

${ }^{10} \mathrm{~J} .-\mathrm{M}$. Larralde, Placement sous ecrou et dignité de la personne, Séance inaugurale du séminaire du recherche "Enfermements, Justice et Libertés", Université Paris I, Panthéon-Sorbonne, the $15^{\text {th }}$ of September 2009, p.15.

${ }^{11}$ J.-P. Duprat, A la recherche d'une protection constitutionnelle du corps humaine, Decision 94-343-344 DC du 27 juillet 1994, LPA, special bioéthique, the 14th of December 1994, n.149, p.34.

${ }^{12}$ Case of Rupa v. Romania, ruling of the $16^{\text {th }}$ of December 2008, $\S 93$.

${ }^{13}$ K. Atilla, România la Curtea Europeană a Drepturilor Omului, "Wolters Kluwer" Publishing House, Bucureşti, 2010, p.47.
} 


\section{RESPECTING THE DIGNITY OF THE HUMAN PERSON IN THE EXECUTION OF \\ SENTENCES AND FREEDOM-DEPRIVING MEASURES RULED BY THE JUDICIARY \\ BODIES DURING A CRIMINAL TRIAL}

Also, according to the practices of the Strasbourg Court, the states have a positive obligation to take whatever measures are necessary to protect the lives of suicidal detainees. Thus, the European Court of Human Rights has retained a violation of art. 2 and 3 of the conventional text in the case of Renold versus France of the 16th of October 2008, when the plaintiff, who was psychologically vulnerable, was arrested and placed into a segregation cell for 45 days. On this occasion the Court has cleared the fact that "mental vulnerability requires particular protection. This is all the more so when a detainee suffering from serious mental problems, as is the case here, is placed in isolation or in a segregation cell for a long time, which is bound to have repercussions on their physical state, given the fact that he had already tried to end his life a few days before" ${ }^{14}$. The treatment of a mentally disordered person can prove incompatible with art. 3 in the Convention, "in terms of the protection of human dignity, even if that person is unable to identify any specific negative effects" 15 .

Moreover, another positive obligation imposed upon the state authorities in art. 3 is to initiate an effective and in-depth official investigation in view of identifying and punishing those people who have inflicted ill treatments.

Ever since the ruling in the case of Mayzit versus Russia ${ }^{16}$ in 2005, the European Court of Human Rights has been referring to the standards of the European Committee for the Prevention of Torture and Degrading or Inhuman Punishments or Treatments (C.P.T.). Therefore, the member states must take them into account when elaborating related policies. The quality of life in prison institutions is of high importance to the C.P.T. and it largely depends on the activities provided for the prisoners and on the general atmosphere of the relationship between the detainees and the prison $\operatorname{staff}^{17}$.

\section{Novelty aspects regarding the respect of the dignity of the human person in the prison environment - Law nr. 254/2013 providing for the execution of sentences and freedom-depriving measures ruled by the judiciary bodies during a criminal trial ${ }^{18}$}

And yet there is a certain reticence related to the idea of protecting the dignity of a person who has committed crimes. For some, "should someone who complies with Kant's criteria, such as the ability to lead a moral life, still have an immoral life style, should we respect them? On the contrary, the fact that that person betrays their ability to lead a moral life is a reason for us to humiliate them for having failed to accomplish their goal, rather than respect them. According to this perspective, those criminals who are still able to be moral deserve no respect, given the fact that they have degraded their humanity - their very nature which was seen as a source of respect for them"19. Or, as President Aharon Barak of the Israeli Supreme Court wrote: „Life in prison (...) does not imply that the arrested person be denied of their right to physical integrity and protection against any violation of their human dignity. An arrested person is denied of their freedom; they should not be deprived of their humanity" 20 .

\footnotetext{
${ }^{14}$ Case of Renold v. France, Decision of the $16^{\text {th }}$ of October 2008.

${ }^{15}$ Ibid.

${ }^{16}$ Case of Mayzit v. Russia, petition nr. 63378/00, Decision of the 20th of January 2005.

${ }^{17}$ The $2^{\text {nd }}$ General Report [CPT/Inf (92)3] showing that over crowdedness leads to a significantly lower quality of life.

${ }^{18}$ Published in the Official Journal of Romania nr. 514 of the $14^{\text {th }}$ of August 2013.

${ }^{19}$ A. Margalit, La société decente, ,Flammarion” Publishing House, Paris, 2007, p. 67.

${ }^{20}$ HCJ 355/79 Katlan v. Prisons Service (1980) IsrSC 34(3) 294, 298.
} 


\section{Bratiloveanu}

From a judicial point of view, a problem arises of knowing how to ensure the respect of dignity, especially in terms of the fundamental rights of the human person ${ }^{21}$. The adoption of Law no. 254/2013 providing for the execution of sentences and freedom-depriving measures ruled by the judiciary bodies during a criminal trial ${ }^{22}$ brings about a change of perspective in terms of the way detainees are treated ${ }^{23}$.

As provided for in art. 4 in this piece of legislation, ,all sentences and freedomdepriving measures shall be executed in such conditions as to ensure the respect of human dignity". According to art. 5 in the law, it is forbidden to subject any person executing a sentence or any other freedom-depriving measure to torture, inhuman or degrading treatments or any other ill treatments; any violation of these provisions shall be punished according to criminal legislation.

According to art.19 of Law no. 254/2013, detainees are subjected to bodily search in view of preventing any special events or risky situations, as well as of retrieving any forbidden objects. Search must be conducted by persons of the same sex as the persons deprived of their liberty in such conditions as to ensure the respect of their dignity. A thorough bodily search must respect the right to private life of the detainee. Search of the body cavities of the detainee can only be conducted by the medical staff. Therefore, searches and physical examinations are generally compatible with the respect of human dignity. Only the fact that they may be conducted by subjecting the person to pointless humiliation or at a high frequency rate (for no apparent reason) may raise a problem in terms of the respect of human dignity.

Ensuring prison security does not only involve avoiding escapes, but also preventing any kind of aggression, suicide or violence. Art. 23 in Law no. 254/2013 mentions the possibilities of the detainees to be temporarily accommodated in a safe room ${ }^{24}$ where they can be supervised at all times by security cameras, should there be any clue that a prisoner intends to recur to self-aggression or suicide, hurt another person, destroy assets or seriously disturb prison order. This measure is taken in view of protecting the detainees and it is limited to a 24-hour time span. It must be applied in such a way as to ensure the respect of human dignity, providing that detainees must not be supervised during their most private moments. Even if there are some serious arguments in favour of supervising prisoners, the authorities must not turn this measure into a permanent one and at some point acknowledge the prevalence of the right to the respect of human dignity of the prisoners. Therefore, they must be allowed to have a minimum of private life, a minimum of privacy, which is part of their personality. The protection of private life implies that any person, including those deprived of their liberty, have a strictly personal space respected, so that they may not have to share their most intimate life experiences or details ${ }^{25}$. In its jurisdictional activity, the Constitutional Court, which

\footnotetext{
${ }^{21}$ C. Jorda, Un espoir pour le respect de la dignité humaine: l'essor de la justice penale internationale, in S. Gaboriau and H. Pauliat, Justice, éthique et dignité. Actes du colloque organisé à Limoges, les 19 et 20 novembre 2004, Pulim, Limoges, 2006, p. 119. In this sense, the Peruvian constitutional court stated that the principle of the dignity of the human person "in its negative side, insists upon the fact that human beings must not be treated as objects or instruments (rather as subjects to rights and obligations), as any person, including criminals, must be treated as a purpose in itself'.

${ }^{22}$ Published in the Official Journal of Romania nr. 514 of the $14^{\text {th }}$ of August 2013.

${ }^{23}$ Law nr. 254/2013 is structured into 7 headings, 24 chapters and 191 articles and came into effect on the 1 st of February 2014.

24 Also known as "the white torture", isolation can seriously violate the rights of the prisoners by its repercussions on their mental health (hallucinations, cognitive and neuro vegetative disorders). In the case of Ireland v. the U.K., the European Court of Human Rights explained that "complete sensory deprivation, doubled by a total social isolation can destroy personality; it is a form if inhuman treatment which should not be accounted for by security requirements". For further details, see the Case of Ireland v. the U.K., in the Commission Report of the 25th of January 1976.

${ }^{25}$ Detainees accommodated in the safe room eat and satisfy their physiological needs in another space than their accommodation.
} 
enforces the supremacy of the Constitution, has connected art. 26 para. (1) to art. 1 para. (3) of the Fundamental Law, in Decision no. $81 / 1994^{26}$, stating that “ $(\ldots)$ in the first paragraph of art. 26 it is mentioned the obligations of the public authorities, ensuring the fulfilment of the provisions in art. 1 para. (3) of the Constitution, according to which "Romania is a democratic and social state ruled by law, wherein human dignity, the rights and liberties of the citizens, the free development of human personality, justice and political plurality are supreme values and are therefore guaranteed".

Taking into account the quality of human person of the detainee depends on the possibility of keeping them attached to the social environment. Detainees have the right to petition, exchange mail, make or receive telephone calls, communicate online, receive visits and be informed about special family situations, receive intimate visits and get married. Persons deprived of their liberty are allowed to receive visits from their family members and from their lawyers; they also have the right to be informed of the serious condition or of the death of their spouse or of one of their close relatives, as soon as the prison administration has been informed of the respective event. The rights granted to the detainees in relation to their family and to the prison staff makes Romanian legislation compliant with the European requirements in this matter ${ }^{27}$.

Harm to human dignity is often perceived as harm to physical integrity, life and health. The life of the detainees must be protected against any harm that may occur generated both by the state and by other detainees. The state has the substantial obligation to protect the lives of the detainees, as well as a procedural obligation to investigate the death of any prisoner.

On one hand, health protection implies that some basic measures be taken in view of protecting the health of the detainees and of preventing their existing illnesses from aggravating. On the other hand, it involves an adaptation of the detention place to the specific situation of the prisoner. Most importantly, health protection involves rest and food, as well as medical examination. Law no. 254/2013 includes provisions related to such situations as a prisoner refusing to eat. In this case, the penitentiary administration has the obligation to temporarily transfer the detainee to a medical institution within the network of the Ministry of Health and inform the family or a close relative of the sentenced person, should their health or bodily integrity be seriously affected by their refusal to eat. According to art.71 of Law no. $254 / 2013$, the right to medical assistance, treatment and care to sentenced persons is guaranteed. The right to medical assistance includes medical intervention, primary, emergency and specialized medical assistance, whereas the right to care includes both health and terminal care. Authorities are obligated to protect the health of the persons deprived of their liberty by providing the necessary medical care related to the disease they have contracted upon incarceration or at a later time. Prisoners have the right to free medical care, treatment and medication. Related to medical examinations, Law no. 254/2013 stipulates distinctive, detailed provisions. The medical examination of the sentences person is performed upon admission and during the execution of the sentence, regularly, confidentially and securely. When given access to medical care, the dignity of the detainees is respected by provisions related to the confidentiality of information [art. 72 para. (2)].

\footnotetext{
${ }^{26}$ Published in the Official Journal of Romania, nr. 14 of the $25^{\text {th }}$ of January 1995.

${ }^{27}$ According to the data provided by the National Administration of Penitentiaries, in 2014 the visit time was maintained to the legal maximum of 2 hours in most penitentiaries; also, the time for making telephone calls was supplemented, to a maximum of 30 minutes a day in most penitentiaries; prison furloughs increased as follows: for 24 hours or less from 1.266 in 2013 to 1995 in 2014 and for 24 hours or more from 398 in 2013 to 627 in 2014; 2-hour intimate visits increased from 9.513 in 2013 to 9.854 in 2014, whereas the 48-hour visits decreased from 635 to 503 .
} 


\section{Bratiloveanu}

Poor detention conditions may negatively influence the health of the detainees. As mentioned above, the material detention conditions can make the object of art. 3 in the conventional text ${ }^{28}$. Here there are provisions related to the right to food, clothes, barrack equipage and minimal accommodation conditions, given the specific international recommendations, especially those of the Committee for the Prevention of Torture ${ }^{29}$. Firstly, according to art. 48 para. (1) of the Law no. 254/2013, the National Administration of Penitentiaries shall take all the necessary measures in view of progressively increasing the number of individual accommodation spaces. Furthermore, para. (3) and (4) of art. 48 stipulate that the sentenced persons are accommodated either alone or along with others, and that the accommodation rooms have both natural lighting and proper artificial lighting ensured by means of the necessary electrical installations. Moreover, according to the law, each sentenced person is provided with a bed and barrack equipment as decided by the general manager of the National Administration of Penitentiaries. The sentenced persons shall wear decent civilian clothes [art. 49 para. (1)]. In terms of food, art. 50 stipulates that the administration of each penitentiary shall ensure the proper conditions for the preparation, distribution and serving of the food in accordance with the norms of food hygiene, age, health condition, type of work, religious beliefs; they also have access to potable water ${ }^{30}$.

In the future, the delinquent shall be seen as a person benefitting from regular rights, as provided for in the recently introduced art.7 of the Law no. 254/2013, according to which "detainees shall exercise all of their civil and political rights except for those which have been denied to them by their permanent sentencing decision as well as those total or partial nonexercise of which inherently result from liberty deprivation or from reasons of maintaining detention security". This view is fully compatible with the respect that person must be shown as human being. The respect of human dignity depends on certain requirements, as human dignity is less a „concrete legal reality, it is rather its realization in each of the fundamental rights" ${ }^{31}$. Dignity is therefore that which must be respected in man as such, it is that which human condition postulates and requires for each person: freedom, identity, chastity, and honour ${ }^{32}$.

\footnotetext{
${ }^{28}$ Presently, the deficit of accommodation places of 4 s.m. is of 11.170 places (as of the $31^{\text {st }}$ of December 2014). The average decreased by 3,65\%, 31.847 detainees in 2014 as compared to 33.053 in 2013. Moreover, there is a decrease of the number of decisions in which the Romanian state was fined by the ECtHR for failing to comply with the detention conditions (29 decisions in 2014 as compared to 32 in 2013). In 2014 Romania had to pay compensations to the amount of 196.400 Euros, as compared to 221.819 Euros in 2013. For further details, see the Annual Report for 2014 of the National Administration of Penitentiaries, available on http://anp.gov.ro. ${ }^{29}$ In the $7^{\text {th }}$ General Report [CPT/Inf (97)10], the C.P.T. emphasized once again the negative effect of over crowdedness and defined an overcrowded prison in a non exhaustive list of characteristics, namely: dirty, cramped spaces, a constant lack of intimacy (even during the use of sanitary utilities), limited outside activities as a result of outnumbered staff and insufficient facilities, overcrowded medical services, high pressure and violence between detainees and in relation to the staff. The C.P.T . concluded that in many cases, the side effects of over crowdedness have led to inhuman and degrading detention conditions. It is noteworthy that in its $11^{\text {th }}$ General Report [CPT/Inf (2001)16], the C.P.T. highlighted the fact that considerable investments in the infrastructure of a penitentiary is not a solution. It is necessary to review the existing practices and legislation in the field of temporary detention, sentence issuance and the available non-depriving sentences. In terms of the minimum space that should be made available for the detainee, the C.P.T. indicated in its $2^{\text {nd }}$ General Report [CPT/Inf (92)3], a minimum of $7 \mathrm{sm} /$ detainee for the cells in police stations, whereas there is no general standard for prison cells. However, reports against different countries mentioned $4 \mathrm{sm} /$ detainee for cells hosting more than one detainee and $6 \mathrm{sm}$. for individual cells. Further information available on http://www.cpt.coe.int/lang/rom/rom-standards.pdf .

${ }^{30} \mathrm{We}$ find it useful to mention that in 2014, the basic cost for detainees was 3.76 lei a day and 535 lei a month.

${ }^{31}$ D. Rousseau, Les libertés individuelles et la dignité de la personne humaine, "Montchrestien » Publishing House, Paris, 1999, p.70.

${ }^{32}$ G. Cornu, Droit civil. Introduction. Les personnes, $13^{\text {th }}$ ed., "Domat Montchrestien" Publishing House, 2007, p.252.
} 
Until present day, the Romanian Constitutional Court ${ }^{33}$ has not been notified in relation to this matter, but it is worth emphasizing the fact that in comparative law it is easily accepted that "even in this case, and especially in this case wherein the distinctive characteristic is individual vulnerability resulting from the lack of freedom, in such environmental conditions as to become severed from the civil society, human dignity is protected by the Constitution through the inviolable rights of man that the detainee also has and has had throughout the execution of their sentence" ${ }^{34}$. Also, the Spanish Constitutional Court mentions that ,applied to the rights of the individuals, the rule in art. 10.1 implies the fact that, being a spiritual and moral value that is inherent to a person, their dignity must stay unaltered whatever the situation that person may be in, including during the execution of a freedom-depriving measure" 35 . It is thus emphasized the strong connection between dignity and the rights of the detainee, wherein the rights are means of protecting dignity.

Human dignity must also be respected when detainees are given disciplinary sanctions. In this sense, art. 101 in Law no. 254/2013 mentions that it is forbidden to apply collective and bodily sanctions and that immobilization and any other degrading or humiliating method may not be used as disciplinary sanctions.

The dignity of a human person is an instrument of interpreting the quality of life in prison, which compels the authorities to withhold from anything that may damage the respect of the detained persons, and then makes the same institutions take actions in order to ensure this respect.

\section{Conclusions}

The adoption of the new Romanian Criminal Code (Law no. 286/2009), of the new Romanian Code of Criminal Procedure (Law no. 135/2010) and of Law no. 254/2013 regarding the execution of sentences and freedom-depriving measures ruled by the judiciary bodies during a criminal trial has generated an important progress regarding the respect of the dignity of the human being. It is not always the case of a direct protection of the dignity of the human person, but rather the protection of their rights, as being those which ensure the protection of dignity. The respect of dignity focuses on the treatment that detainees receive as human beings and it becomes increasingly important.

In the field of the rights of the detained persons, a new approach of the protection of life focuses on the need to ensure quality in the lives of the persons deprived of their liberty, stipulating the interdiction of incarcerating the detainee in conditions which prove too hard for their human condition. Therefore, respecting the dignity of the human person in the detention places implies a more human nature of the places and people. Transposing the dignity of the

\footnotetext{
${ }^{33}$ In Ruling nr. 1/2012 for the admission of the objection of unconstitutionality of the provisions of the law which modified and amended the G.E.O. nr. 155/2001 regarding the approach of the management program for stray dogs, as approved by Law no. 227/2002, as well as, especially, the provisions of art. 1 pt. 5 (referring to art. 4 para. (1)), pt. 6 (referring to art. 5 para. (1) and (2)), pt. 8, pt. 9 (referring to art. 8 para. (3) pts. a)-d)), pt. 14 (referring to art. 13 (1) and 13 (4)), pt. 15 (referring to art. 14 para. (1) let. b) of the law), the Romanian Constitutional Court mentioned that human dignity implies two inherent dimensions, namely: human relationships, focusing on the right and obligation of man to have their rights and fundamental freedoms respected and respect them in their turn, and the relation between man and the environment, including the animal world, which implies that man has the moral obligation to care for these beings so as to prove their level of civilization.

34 The Italian Constitutional Court, Decision no. 26/1999, quoted by M. Di Ciommo, Dignità umana e stato costituzionale, „Passigli Editori” Publishing House, 2010, p.159.

${ }_{35}$ The Constitutional Court of Spain, STC 120/1990, FJ4, quoted in Véronique Gimeno-Cabrera, Le traitement jurisprudentiel du principe de dignité de la personne humaine dans la jurisprudence du Conseil constitutionnel français et du Tribunal constitutionnel espagnol, „L.G.D.J.” Publishing House, Paris, 2004, p. 131. Similarly, $\S 139$ of the Constitution of the German Kingdom, of March 1849, according to which a free people must respect human dignity, even in the case of a criminal.
} 


\section{Bratiloveanu}

human being to the prison environment generates a radical change of perceptions related to prison, prisoners and the way in which they are treated.

\section{Bibliography}

M. Di Ciommo, Dignità umana e stato costituzionale, „Passigli Editori” Publishing House, Firenze, 2013;

K. Attila, România la Curtea Europeană a Drepturilor Omului, „Wolters Kluwer” Publishing House, Bucureşti, 2010;

S. Tzistis, Humanisme, dignité de la personne et droits des détenus, Etudes et analyses de l'Institut pour la Justice, 2009;

J.-M. Larralde, Placement sous écrou et dignité de la personne, séance inaugurale du séminaire de recherche „Enfermement, Justice et Libertés”, Université Paris I PanthéonSorbonne, 2009;

G. Cornu, Droit civil. Introduction. Les personnes, „Domat Montchrestien” Publishing House, Paris, 2007;

A. Margalit, La société decente, „Flammarion” Publishing House, Paris, 2007;

Simone Gaboriau, Hélène Pauliat, Justice, éthique et dignité. Actes du colloque organisé à Limoges, le 19 et 20 novembre 2004, Pulim, Limoges, 2006;

Véronique Gimeno-Cabrera, Le traitement jurisprudential du principe de la dignité de la personne humaine dans la jurisprudence du Conseil constitutionnel français et du Tribunal constitutionnel espagnol, „L.G.D.J.” Publishing House, Paris, 2004;

D. Rousseau, Les libertés individuelles et la dignité de la personne humaine, „Montchrestien” Publishing House, Paris, 1999;

J.-P. Duprat, A la recherche d'une protection constitutionnelle du corps humaine, decision 94-343-344 DC du 27 juillet 1994, L.P.A., special bioéthique, 1994, no. 149;

M. De Montaigne, Essais, „P.U.F.” Publishing House, Paris, 1992. 